\title{
Urotensin II receptor determines prognosis of bladder cancer regulating cell motility/invasion
}

\author{
Renato Franco ${ }^{1 \dagger}$, Silvia Zappavigna ${ }^{2 \dagger}$, Vincenzo Gigantino ${ }^{1}$, Amalia Luce ${ }^{2}$, Monica Cantile ${ }^{1}$, Margherita Cerrone ${ }^{1}$, \\ Gaetano Facchini ${ }^{3}$, Sisto Perdonà ${ }^{3}$, Sandro Pignata ${ }^{3}$, Giuseppe Di Lorenzo ${ }^{4}$, Sergio Chieffi ${ }^{5}$, Giovanni Vitale ${ }^{6}$, \\ Marco De $\mathrm{Sio}^{7}$, Alessandro Sgambato ${ }^{8}$, Gerardo Botti ${ }^{1}$, Ali Munaim Yousif ${ }^{9}$, Ettore Novellino ${ }^{9}$, Paolo Grieco ${ }^{9}$ \\ and Michele Caraglia ${ }^{*}$
}

\begin{abstract}
Background: Non Muscle Invasive Bladder Transitional Cancer (NMIBC) and Muscle Invasive Bladder Transitional Cancer (MIBC)/invasive have different gene profile and clinical course. NMIBC prognosis is not completely predictable, since the relapse rate is higher than $20 \%$, even in the form of MIBC. The aim of this study is to evaluate if UTR expression can discriminate between NMIBC and MIBC and predict the risk of relapses in NMIBCs.

Methods: We have investigated upon urotensin-II (UII) receptor (UTR) expression in vivo in 159 patients affected by NMIBC. The biological role of UTR was also investigated in vitro. UTR expression was evaluated in a tissue-micro-array, consisting of normal, NMIBC and invasive bTCC samples.

Results: UTR discriminated between NMIBC and MIBC and showed a significant correlation between low UTR expression and shorter disease free survival in NMIBC. The superagonist UPG84 induced growth suppression at nM concentrations on 3/4 cell lines. Bladder cancer cell treatment with the antagonist urantide or the knock-down of UTR with a specific shRNA significantly blocked both the motility and invasion of bladder cancer cells.

Conclusions: The evaluation of UTR expression can discriminate between NMIBC at high and low risk of relapse. Moreover, our data suggest that UTR is involved in the regulation of motility, invasion and proliferation of bladder cancer cells. High UTR expression is an independent prognostic factor of good prognosis for NMIBC regulating motility and invasion of bladder cancer cells.
\end{abstract}

Keywords: Bladder cancer, Muscle invasive, Non-muscle invasive, Tumor progression, Urotensin-II

\section{Background}

Bladder transitional cell carcinoma (bTCC) represents the $4^{\text {th }}$ most common malignancy in the world [1]. Tumors not invading into muscularis propria, include non invasive papillary TCC (pTa), carcinoma in situ (CIS) (pTis), and tumors invading into lamina propria (pT1): "Non-Muscle Invasive bladder transitional cancer" (NMIBC). Invasive tumors infiltrate muscolaris propria: "Muscle-Invasive bladder transitional cancer" (MIBC) [2,3]. NMIBC tumors have a quite favourable clinical outcome while a high mortality rate has been reported for invasive tumors. About

\footnotetext{
* Correspondence: michele.caraglia@unina2.it

${ }^{\dagger}$ Equal contributors

${ }^{2}$ Department of Biochemistry, Biophysics and General Pathology, Second University of Naples, Naples, Italy

Full list of author information is available at the end of the article
}

$60 \%$ to $70 \%$ of NMIBC recur, and about $15 \%$ to $25 \%$ of patients relapse with invasive bladder cancer [4]. Histopathological stage and grade are currently the two most important factors in determining behaviour and treatment plan for bladder tumors [5]. Prognosis of NMIBC remains unpredictable for both recurrence and progression.

Many biomarkers have been proposed and within them, p53-dependent deregulated pathways seem to be strongly associated to invading tumors [6]. Moreover, bTCC could promote its growth and progression through autocrine/ paracrine regulator peptides, such as vascular endothelial growth factor (VEGF) and proepithelin [7-11].

Recently, Urotensin-II receptor (UTR) has been detected in several tumor cell lines but there are conflicting results about its role in tumor progression $[12,13]$.

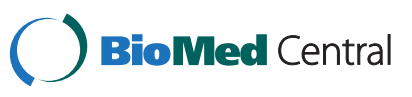

(c) 2014 Franco et al.; licensee BioMed Central Ltd. This is an Open Access article distributed under the terms of the Creative Commons Attribution License (http://creativecommons.org/licenses/by/4.0), which permits unrestricted use, distribution, and reproduction in any medium, provided the original work is properly credited. The Creative Commons Public Domain Dedication waiver (http://creativecommons.org/publicdomain/zero/1.0/) applies to the data made available in this article, unless otherwise stated. 
Treatment with UTII significantly increases human adrenocortical and renal cell carcinoma proliferation $[14,15]$. In lung adenocarcinoma, it has been demonstrated that treatment with UTII, produced an increased tumor volume in vitro and in vivo [16].

Our group has recently demonstrated that UTR low expression in prostate adenocarcinoma was significantly associated to both shorter disease free survival (DFS) and overall survival (OS) [12].

In this study, we evaluated UTR expression in a series of bladder cancer cell lines and its involvement in the regulation of biological functions like invasion and motility of bladder cancer cells.

\section{Methods}

\section{Bladder cancer TMA building}

A progressive Tissue Micro-Array (TMA), has been constructed using 130 tissue samples (113 tumour and 17 normal tissues), after pathologic re-evaluation according WHO/ISUP 2007 [17].

Tumor tissues included 36 NMIBC and 77 MIBC. All tumours and controls have been reviewed by two experienced pathologists (RF, GB). Tissue cylinders were brought into one recipient paraffin block using a semiautomated tissue arrayer (Galileo TMA).

The bladder cancer samples were collected from the National Institute of Tumours of Naples after Internal Ethical Institutional approval in compliance with the Helsinki Declaration

\section{Patients and specimens of prognostic series of NMIBC}

159 patients, undergone to bladder biopsy from 2000 to 2008 at the National Cancer Institute "Fondazione Giovanni Pascale" of Naples have been included in this study. 84 (53\%) of 159 patients showed relapses. All cases were reviewed according to WHO classification criteria [17].

Medical records have been reviewed for clinical information, including histologic parameters assessed on standard H\&E-stained slides.

\section{Immunohistochemistry analysis}

Immunohistochemical staining was done on slides from formalin-fixed, paraffin embedded tissues, to evaluate UTR expression. After protein block, slides were incubated with primary anti-UTR antibody followed by secondary antibody (Novocastra Streptavidin-HRP) and

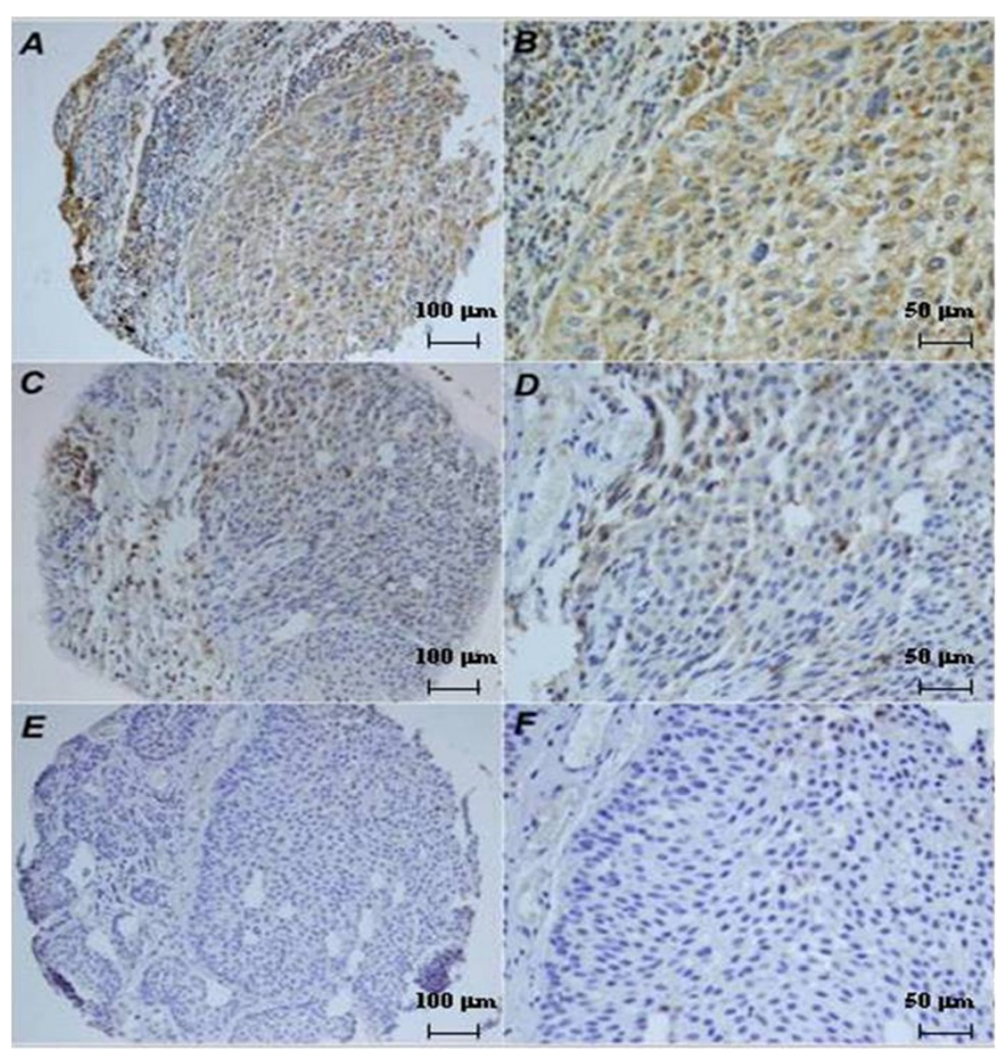

Figure 1 Immunohistochemical UTR expression in a progressive Bladder TMA. A,B): High UTR expression in NMIBC (20x and 40x); C,D): low UTR expression in MIBC (20x and 40x). E,F): negative UTR expression in invasive tumor (20x and 40x). 
Table 1 Clinical-pathological characteristics of the Superficial TCC patients

\begin{tabular}{llll}
\hline & & $\begin{array}{l}\text { UTR Low } \\
\text { expression }\end{array}$ & $\begin{array}{l}\text { UTR High } \\
\text { expression }\end{array}$ \\
\hline Patients without relapse (84) & 38 & 46 \\
Sex & Male & 28 & 37 \\
\multirow{3}{*}{ Grade } & Female & 10 & 9 \\
& High grade & 11 & 8 \\
\multirow{2}{*}{ Infiltration } & Low grade & 27 & 38 \\
\multirow{2}{*}{ Patients with subsequent relapse (75) } & 56 & 35 \\
\multirow{2}{*}{ Sex } & No infiltration & 26 & 11 \\
\multirow{2}{*}{ Grade } & Male & 47 & 13 \\
& Female & 9 & 6 \\
\multirow{2}{*}{ Infiltration } & High grade & 16 & 6 \\
& Low grade & 40 & 13 \\
& No infiltration & 34 & 11 \\
\hline
\end{tabular}

then visualized using a 3,3'-diaminobenzidine. Sections were counterstained with hematoxylin and mounted.

\section{RNA extraction and analysis}

Total RNA was isolated from FFPE biopsies of prognostic series whole section, collected in National Cancer Institute "Fondazione G. Pascale" Institutional Bio-Bank, using High pure FFPE RNA Micro Kit (Roche). RNA was subjected to cDNA synthesis using the Ready To Go You-Primer
First-Strand Beads kit (Amersham Biosciences) in a reaction mixture containing random hexamers (Applied Biosystems).

\section{Real-time PCR}

Quantitative RT-PCR was performed in a LightCycler system (Roche) using TaqMan ${ }^{\circ}$ analysis. All reactions were performed in triplicate. The thermal cycling conditions included a step of $20 \mathrm{sec}$ at $95^{\circ} \mathrm{C}$ followed by 40 cycles of $95^{\circ} \mathrm{C}$ for $1 \mathrm{sec}$ and $60^{\circ} \mathrm{C}$ for $20 \mathrm{sec}$. Comparative $C_{\mathrm{t}}$ method was used to determine human UTR gene variation, using as reference gene TaqMan Endogenous Controls Human ACTB ( $\beta$-actin) Endogenous Control (RealTime Designer Assay, Roche). We identified a calibrator cell line (LNCaP) that represents the unitary amount of the target, consequently the samples express $n$-fold mRNA relative to the calibrator.

\section{Statistical analysis}

UTR immunohistochemistry expression was evaluated in bladder cancer TMA including normal, NMIBC and invasive samples. The mean and median tissue UTR expression, expressed as a percentage of immunoreactive cells, was calculated. Kruskal-Wallis test identified differences in median expression values. Selection of the median value as cut-off score was based on evaluation of the distribution of UTR scores. Differences in the number of negative and positive cases were analyzed using a test of equal proportions.

UTR expression was then evaluated on a prognostic series of NMIBC with complete clinical-pathological information.

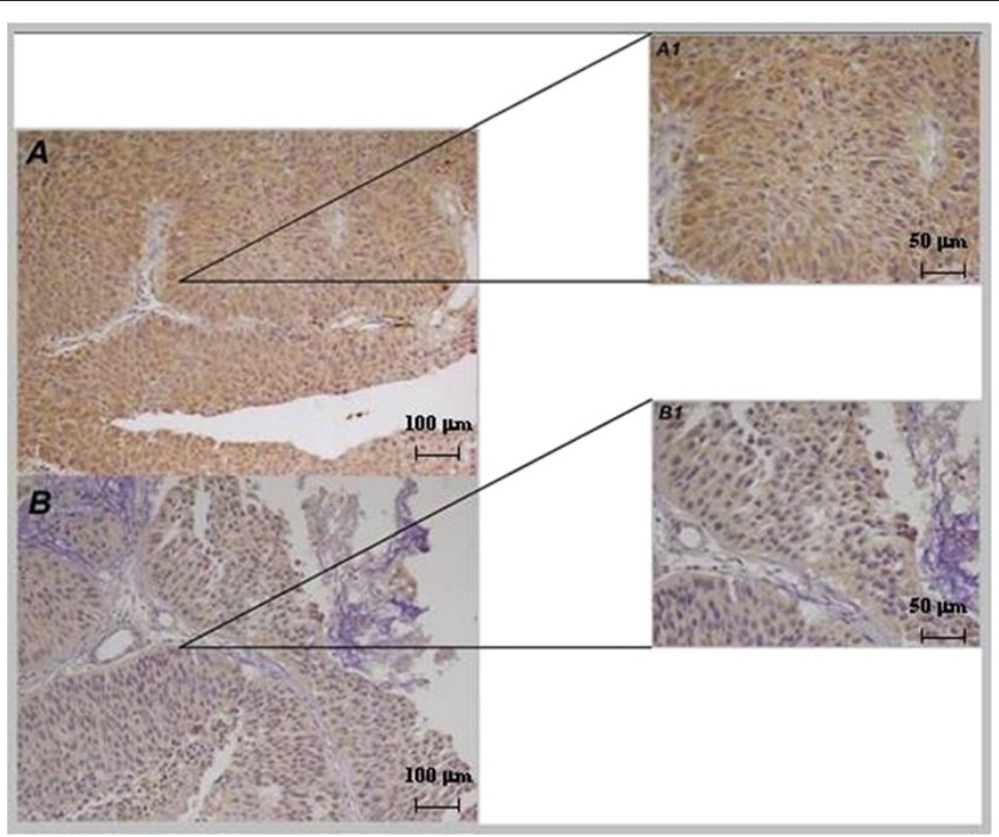

Figure 2 Immunohistochemical UTR expression in NMIBC. A, A1): High UTR expression (20x, 40x) in a patient without recurrence; B, B1): low UTR expression $(20 x, 40 x)$ in a patient with recurrence. 


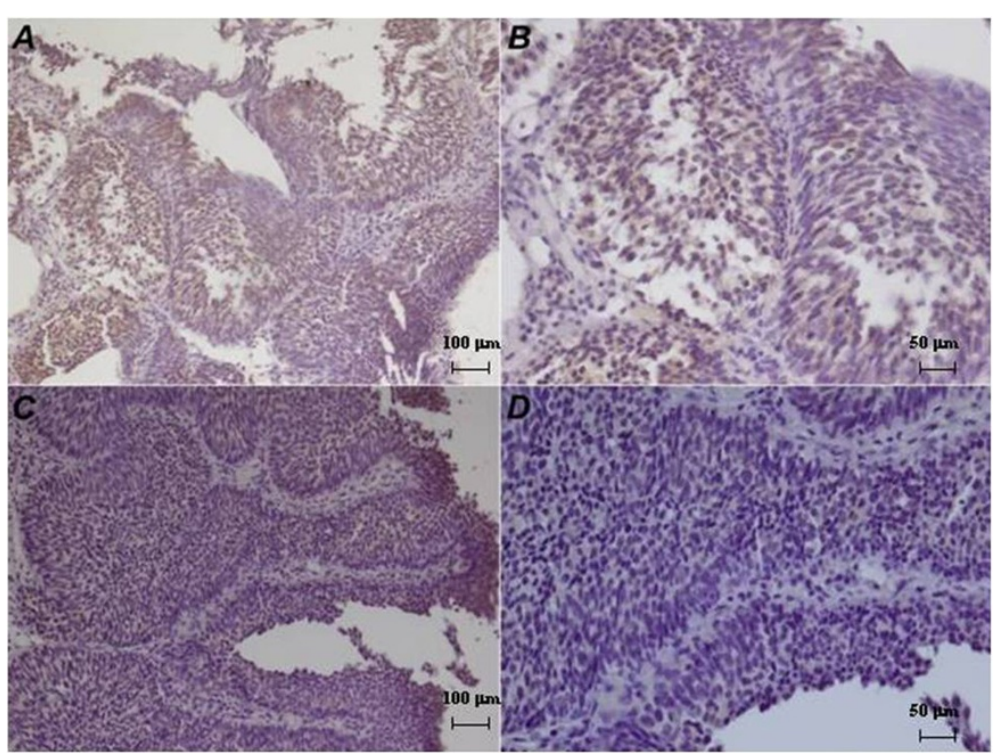

Figure 3 Immunohistochemical UTR expression in a patient with no recurrence. A, B: High UTR expression (20X, 40X) in a patient who has not developed a relapse; C, D: low UTR expression (20x, 40x).

Association between UTR expression and other molecular and clinical-pathological parameters was calculated using contingency table methods and tested for significance using the Pearson chi-squared test. Univariate and multivariate relative risks have been calculated using the COX proportional hazards regression. All calculations have been performed using the SPSS (Statistical Package for the Social Science rel.13) software (Chicago, IL) and the results have been considered statistically significant when P-value has been $\leq 0.05$.

\section{Cell lines and cell proliferation by MTT assay}

hUII and urantide, the agonist-antagonistic compounds of UII, UPG83, UPG84 and UPG85 were all provided by Prof. P. Grieco [18].
HT1376, MCR, T24 and RT112, cell lines of human bladder cancer, were provided by ATCC. HT1376 and T24 are a grade 3 whereas RT112 is a grade 2 urinary bladder cell line. Cell lines were plated in 96-well plates and one day later were treated with different compounds at concentrations ranging from 10 to $1,000 \mathrm{nM}$ (urantide, UII, UPG83 and UPG85) or with concentrations ranging from 10 to 2,000 $\mathrm{nM}$ (UPG84). Cell proliferation was evaluated by MTT assay [19].

\section{Western blot analysis}

Total proteins were prepared as described [19]. Membranes were incubated with the following primary antibodies: (a) anti-UTR; (b) anti- $\alpha$-tubulin. Bound antibodies were detected by horseradish peroxidase-conjugated secondary antibodies, followed by enhanced chemiluminescence [19].
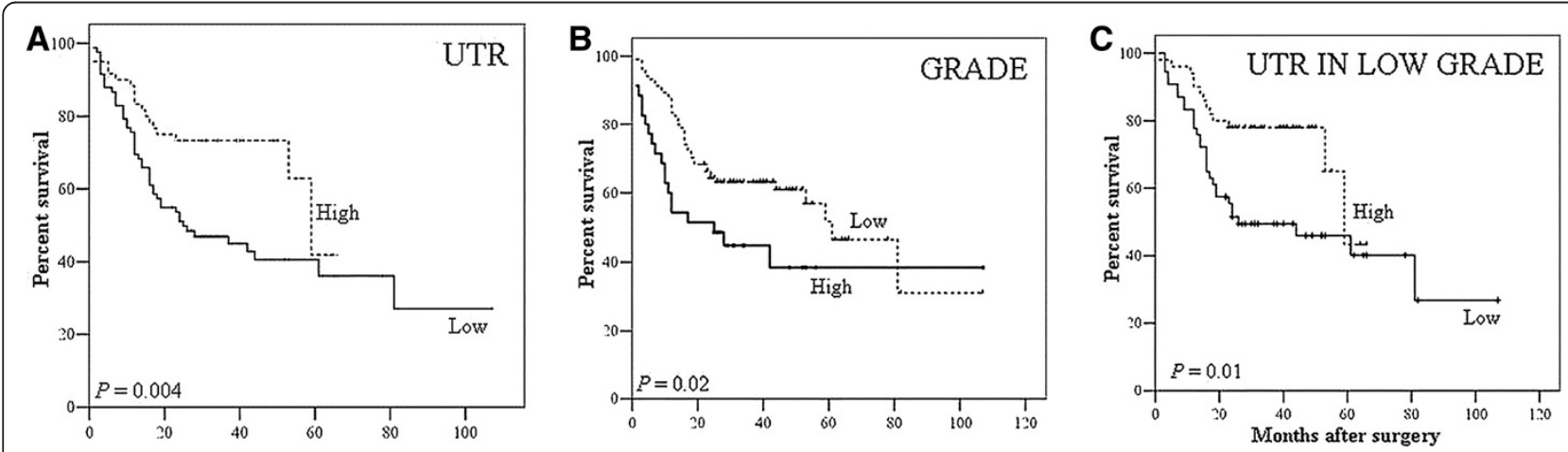

Figure 4 Kaplan-Meier survival curve. A) Association between low UTR expression and shorter time of relapse. B) Association between tumor grade and shorter time of relapse. C) Shorter disease-free survival is associated to low UTR expression also in the low grade carcinoma group. 


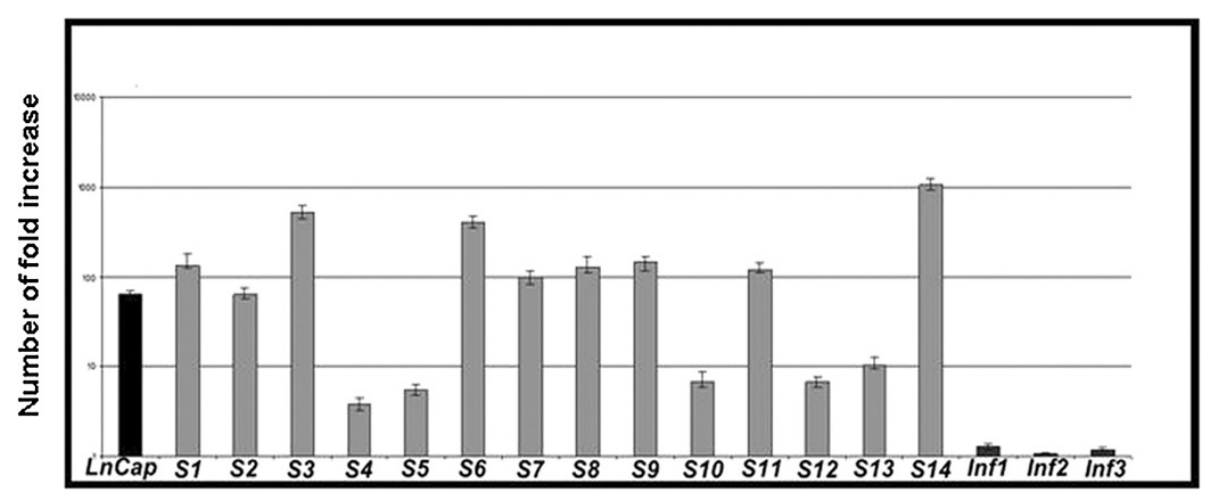

Figure 5 Real time UTR mRNA quantification in bladder samples. LNCaP: calibrator; S: superficial bladder tumors; Inf: invasive bladder tumor. Data were expressed as mean \pm standard deviation $(S D, n=3)$.

FACS analysis of UTR expression in bladder cancer cells For determination of cell surface UTR expression, analysis was performed using indirect UTR staining at FACS. We have seeded and treated or not cells with $10 \mathrm{nM}$ urantide or UPG84 for $72 \mathrm{~h}$. After treatment, cells were centrifuged and $4 \%$ paraformaldehyde was added for $15 \mathrm{~min}$ at $4^{\circ} \mathrm{C}$ in the dark. Cells were incubated in $\mathrm{PBS} / \mathrm{BSA}$ for $10 \mathrm{~min}$ at $4^{\circ} \mathrm{C}$ and subsequently with a primary rabbit polyclonal antibody raised against human UTR (GPR14) or with an irrelevant immunoglobulin (IgG1) or in PBS and processed as previously described [19].

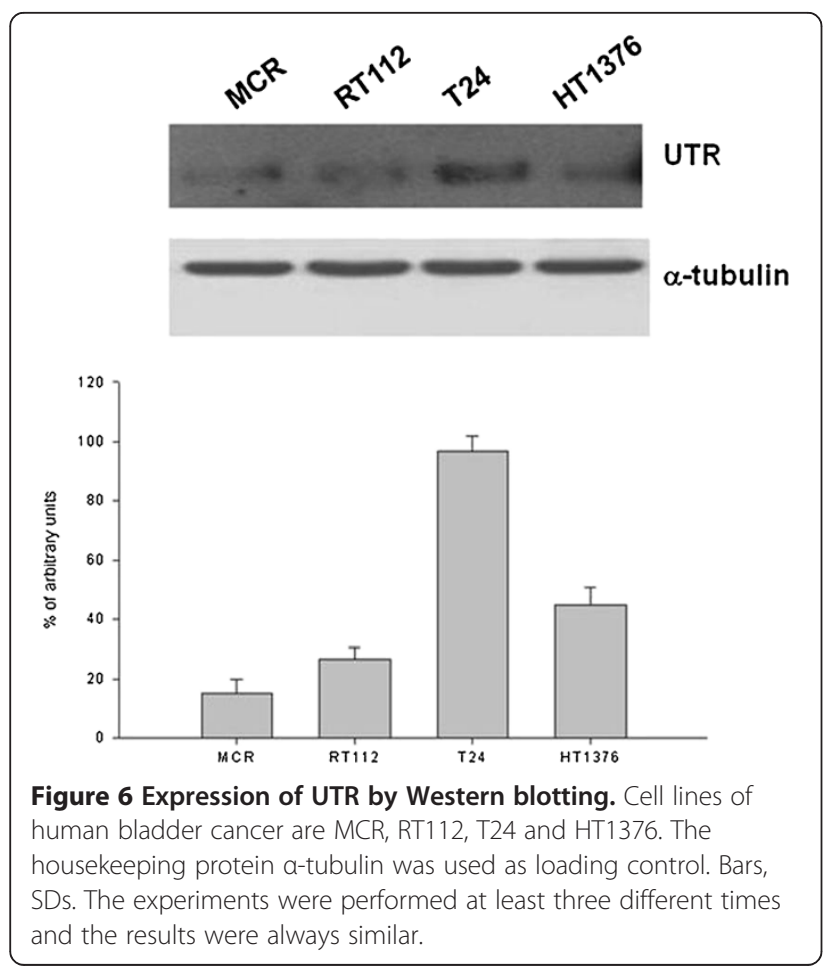

\section{Invasion and motility assays}

For invasion assays, $8 \mu \mathrm{m}$ inserts (Falcon) were employed and Matrigel TM (Sigma) was diluted in serum-free medium. Subsequently, assays were performed as previously reported [20].

\section{Results}

\section{UTR expression was higher in NMIBC}

We have evaluated UTR expression on a progressive bladder TMA. We have found a mean expression of UTR of about $16.67 \%$ and $13.57 \%$ for NMIBC and MIBC, respectively. Percentage of negative cases was significantly higher in MIBC than NMIBC. Pearson chi-squared test showed significant higher UTR expression in NMIBC $(p=0.0001)$ (Figure 1$)$. These results suggest a higher expression of UTR in NMIBC.

\section{UTR expression correlated with low risk of relapses in NMIBCs.}

Our series included 125 males and 34 females, 118 (74\%) older than 60 years of age (mean age 68, range from 40 to 88 years). The anatomic sites of the tumour were lateral wall in 87 cases (55\%), cupola in 13 cases (8\%), trigon in 51 cases (32\%). Relapses have been recorded in 75 patients (47\%), from 1 (57) to 6 (1) total episodes (Table 1).

High-grade primitive tumours have been observed in 41 patients (26\%); the relapse tumor grade was the same of primitive tumors in 71 cases $(94 \%)$, while 4 cases $(6 \%)$ of the relapsed tumours showed higher grade than the primary. In 53 cases (33\%) lamina propria infiltration was observed (Table 1).

High expression was recorded when positive cells were $>30 \%$. Patients with low expression of UTR were 94 (59\%), in particular 38 (40\%) without recurrences and 56 (60\%) with histologically documented recurrences. Moreover, 65 patients (41\%) showed high expression of UTR, 46 (71\%) without recurrences and 19 (29\%) with 


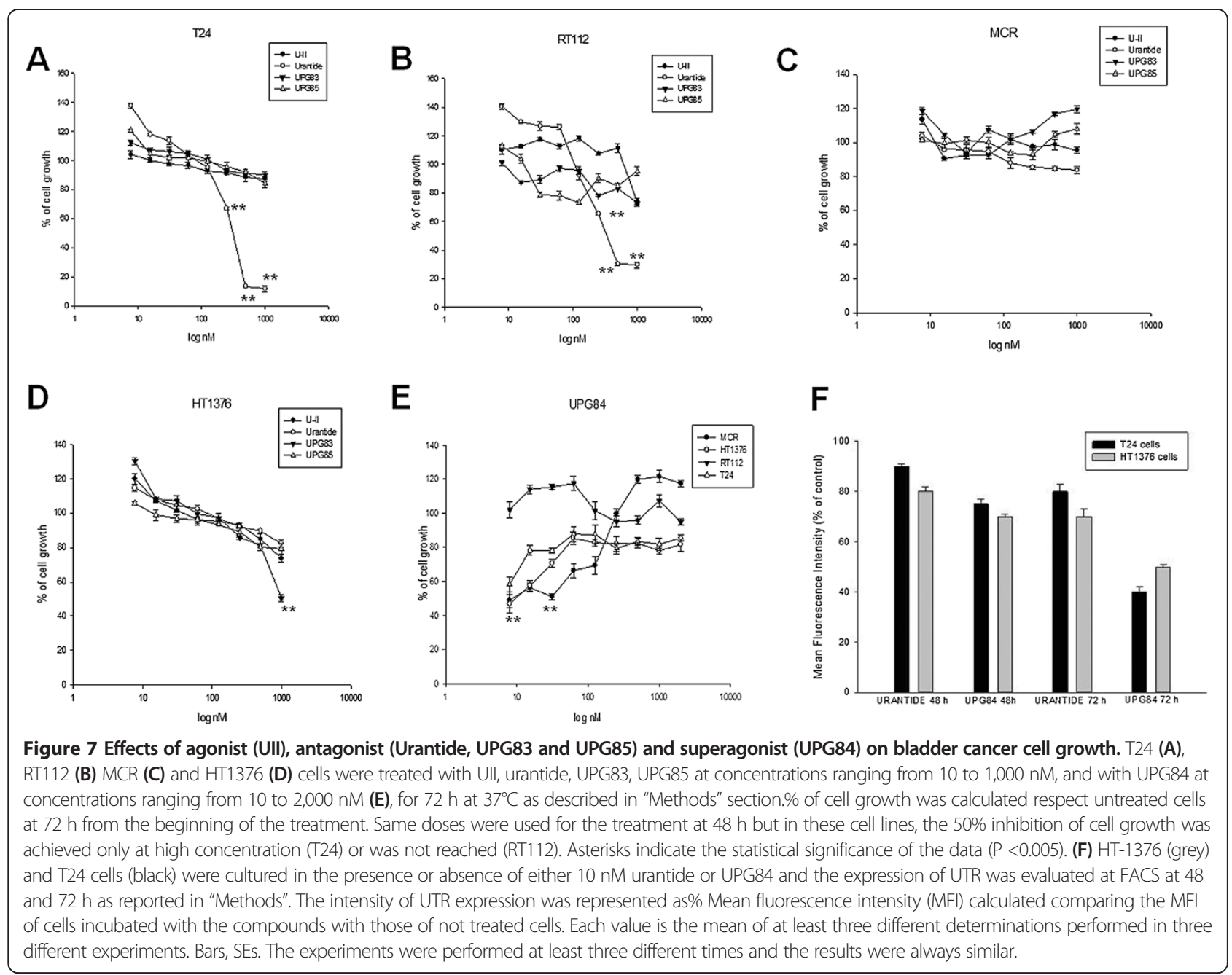

recurrences. High UTR expression was significantly associated to low grade carcinoma $(\mathrm{p}=0.044)$ while low expression was associated to cases that have developed at least one relapse $(\mathrm{p}=0.001)$. Moreover, UTR expression in relapses was significantly lost respect to primary tumors $(\mathrm{p}=0.025)$ (Figures 2 and 3$)$.

The decrease of the correlation between high UTR expression and absence of relapse was likely due to the short time of observation that could explain the

Table 2 IC:50s at $\mathbf{7 2}$ h of different UTR agonists and antagonists on bladder cancer cell lines

\begin{tabular}{llllll}
\hline Cell lines & \multicolumn{6}{l}{ Compounds IC:50 (nM) } \\
\cline { 2 - 6 } & UII & Urantide & UPG83 & UPG85 & UPG84 \\
\hline T24 & n.d. & $350 \pm 8$ & n.d. & n.d. & $7 \pm 0,6$ \\
RT112 & n.d. & $375 \pm 6$ & n.d. & n.d. & n.d. \\
MCR & n.d. & n.d & n.d. & n.d. & $9,8 \pm 0,5$ \\
HT1376 & n.d. & n.d. & $1000 \pm 9$ & n.d. & $7,9 \pm 0,4$ \\
\hline
\end{tabular}

n.d.: not detectable; IC:50: drug concentration that induces the $50 \%$ of cell growth inhibition after $72 \mathrm{~h}$ from the beginning of the treatment; UII: urotensin II. presence of some patients who will develop the relapse in the following observation time (likely expressing low UTR levels).

\section{UTR expression was directly correlated with DFS}

Considering only first relapse, we recorded a significant association between low UTR expression and shorter time to relapse $(\mathrm{p}=0.004)$. As expected tumor grade was associated to recurrence $(\mathrm{p}=0.02)$ (Figure 4$)$. Also considering low grade carcinoma group, shorter DFS was associated to UTR low expression $(\mathrm{p}=0.01)$ (Figure 4$)$.

In a multivariate analysis including UTR expression and grade, only UTR appeared to be an independent prognostic factor $(\mathrm{p}=0.025)$.

\section{UTR protein expression modulation was due to changes} in its mRNA levels in bTCC.

UTR gene expression was evaluated on $\mathrm{LNCaP}$ cell line and 14 NMIBC and 3 invasive MIBC samples by Real-Time PCR quantification. 


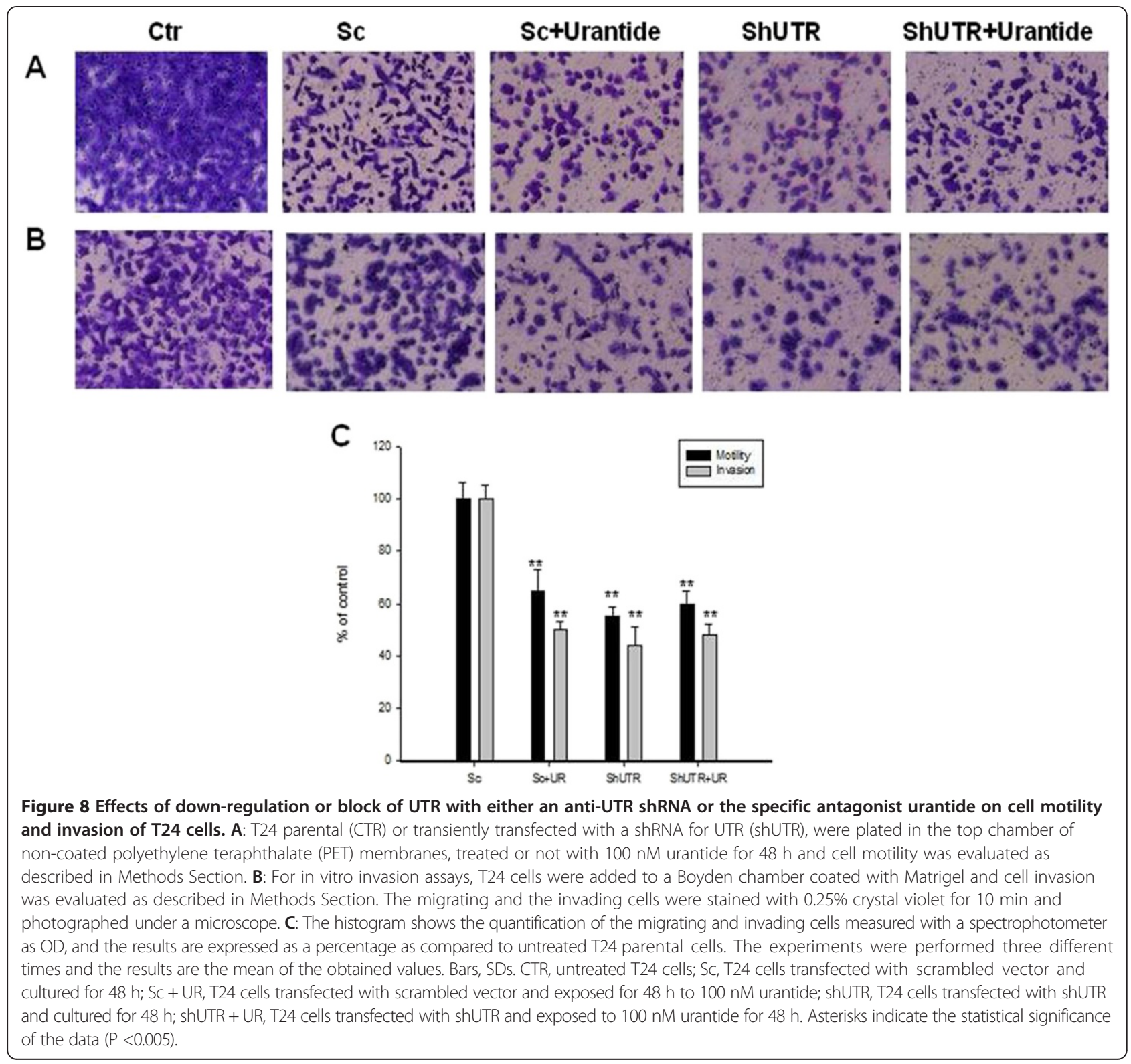

In LNCaP, UTR expression was moderate. In 4 NMIBC samples the expression was low while in 3 samples the increase of expression was moderate. The most part of NMIBC showed a significant increase in UTR mRNA expression (Figure 5). UTR gene expression was very low in all invasive bTCC selected (Figure 5). Moreover, UTR mRNA levels correlated with the expression of the protein in all examined cancer samples.

\section{In vitro effects of UII, Urantide, and other agonist/ antagonist ligands (UPG85, UPG84 and UPG83) on bladder cancer}

In order to evaluate the involvement of UTR-dependent signaling pathway on the growth of bladder cancer cells, biological effects of human agonists (UII and UPG84), and antagonists (urantide, UPG83 and UPG85), were evaluated on proliferation of human bladder cancer cell lines MCR, RT112, T24 and HT1376 (Figure 6) after $72 \mathrm{~h}$ of treatment. UII had no significant effects on the proliferation of all cell lines (Figure 7A-D). The 50\% growth inhibitory concentration (IC:50) of urantide was $350 \mathrm{nM}$ in T24 and $375 \mathrm{nM}$ in RT112 while it was not achieved in HT1376 and MCR cells (Table 2). UPG84 induced $45-50 \%$ growth inhibition at a concentration close to the supposed Kd of UTR (about $10 \mathrm{nM}$ ) in all cell lines with the exception of RT112 cells that were almost insensitive (Figure 7E). Interestingly, UPG84 is a superagonist of UTR (Additional file 1: Table S1) and the addition to cell culture for $72 \mathrm{~h}$ could affect UTR expression on cell surface for internalization process triggering. On this light, 
we have found that treatment of these cells with UPG84 induced a time-dependent down regulation of UTR expression that reached an about $50 \%$ and $60 \%$ decrease at $72 \mathrm{~h}$ from the beginning of the treatment on HT-1376 and T24 cells, respectively (Figure 7F). On the other hand, urantide induced 30 and $20 \%$ decrease of UTR expression in HT-1376 and T24 cells, respectively (Figure 7F).

\section{Effects of Urantide and UTR knock-down on motility and invasion of bladder cancer cells}

In order to explore the specific contribution of UTR in regulation of motility and invasion of bladder cancer cells, T24 and RT112 cells were treated with urantide $(100 \mathrm{nM})$ for $48 \mathrm{~h}$ and/or were transiently transfected with shRNA for UTR to down-regulate UTR protein expression. Cells were seeded in transwell chambers and allowed to migrate and invade in absence or presence of urantide. After $48 \mathrm{~h}$, urantide induced an about 35\% and $50 \%$ reduction of cell motility and invasion, respectively, in T24 cells if compared to untreated cells. When T24 cells were transfected with shUTR displayed $45 \%$ and $56 \%$ inhibition of their ability to migrate and invade, respectively (Figure 8A and B, respectively). Downregulation of UTR in T24 treated with urantide did not increase the effect induced by urantide alone (Figure 8A and B, respectively). Similar results were also obtained in RT112 (Figure 9A and B). These data demonstrated that UTR is involved in both motility and invasion of human bladder cancer cells.

\section{Discussion}

NMIBC is characterized by a wide range of neoplastic proliferation with a high propensity to recur and a not negligible tendency to progress to MIBC [21]. Currently, both

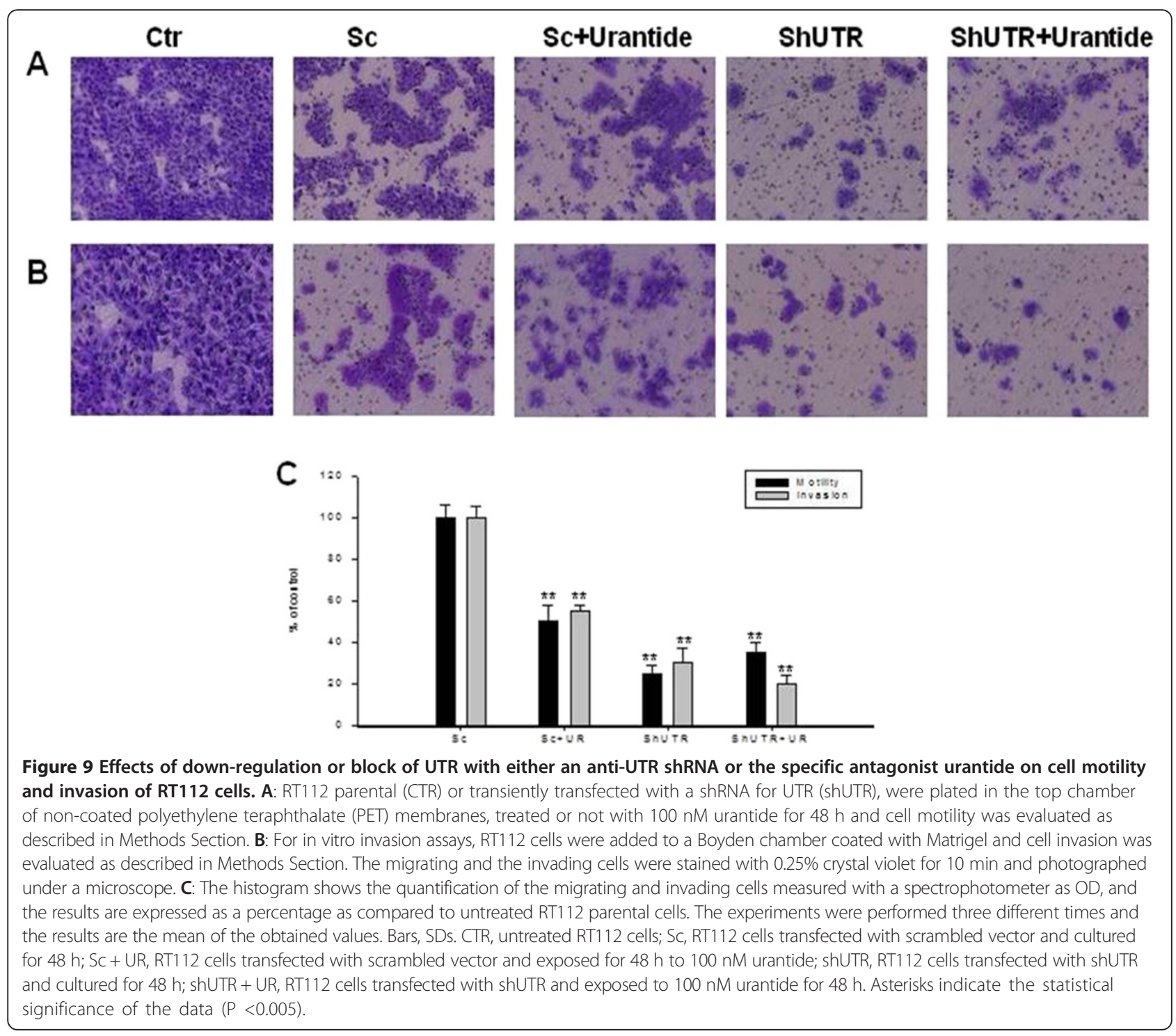


tumour stage and grade at diagnosis are considered the most important predicting factors of progression in NMIBC $[22,23]$. Interpretation of histopathologic criteria can also be hampered by significant variability among pathologists [24]. On these bases, molecular markers predictive of progression in NMIBC are urgently needed. Identification of gene expression profile of NMIBC helped to prognostic stratification of patients, in order to recognize high-risk patients in terms of tumor progression [25]. However, although extensive efforts, no promising markers suggested by several groups have yet been able to meet these criteria [26].

UII and its receptor are widely expressed and UII represents a potent endogenous vasoconstrictor with physiological mechanisms similar to other potent mediators [27]. In literature, there are several evidences that associate the altered expression of UTR in many cell lines and tumor tissues [28,29].

In some cases it is described an up-regulation of UTR/UII pathway, in others a down regulation correlated to tumour progression $[14,15]$. In this light, we have previously demonstrated that UTR expression correlates with good prognosis of prostate cancer and is able to discriminate patients with good from those with bad prognosis and with Gleason grade more than 7 and we have also reported that UTR is likely involved in the regulation of prostate cancer cell motility and invasion [12].

On these bases, we have analysed UTR expression in bTCC samples. In this manuscript, we clearly show that UTR expression is able to discriminate between NMIBC and MIBC and is an independent predictive marker of relapse in NMIBC.

UTR mRNA expression on a selected group of bladder cancers suggested that the regulation of UTR in bladder cancers was dependent upon its mRNA levels.

We also investigated upon UTR biological role in bladder cancer cell lines. We have assessed biological effects of human agonist (UII), synthetic agonist (UPG84) and antagonists (urantide, UPG83 and UPG85) on the proliferation of human bladder cancer cell lines. UII, UPG85 and UPG83 had no significant effects on cell growth while UTR antagonists urantide and superagonist UPG84 inhibited cell growth. Interestingly, the latter was more potent than urantide reaching an about $50 \%$ growth inhibition after $72 \mathrm{~h}$ of treatment on 3 out of 4 cell lines examined at a concentration near to the supposed Kd of UTR. This effect could be ascribed to UTR downregulation induced by the superagonist likely due to the induction of its internalization and subsequent degradation.

Since UTR seems to be involved in the regulation of intracellular $\mathrm{Ca}^{++}$levels correlated with cell contraction and cytoskeleton changes, we have evaluated effects of shUTR and urantide on both motility and invasion of RT112 and T24 cells [30,31]. Indeed, we found that downregulation of either the function or expression of UTR had significant effects on both motility and invasion of bladder cancer cells and that its down-regulation caused by the specific shRNA induced biological effects similar to those triggered by the addition of antagonist in T24 and was even more potent in RT112.

\section{Conclusions}

We have studied the biological role of UTR in bladder cancer and obtained data suggesting its involvement in the regulation of cell motility and invasion. These data suggest that UII/UTR mediated pathway may play a role in bladder cancer progression. Finally, UTR expression can be an independent predictive factor of progression in NMIBC patients.

\section{Additional file}

Additional file 1: Table S1. Receptor Affinity and Biological Activity of Analogues of Urotensin-II used in this study.

\section{Abbreviations}

NMIBC: Non muscle invasive bladder transitional cancer; MIBC: Muscle invasive bladder transitional cancer; UII: Urotensin-II; UTR: Urotensin-II receptor; bTCC: Bladder transitional cell carcinoma; CIS: Carcinoma in situ; VEGF: Vascular endothelial growth factor; DFS: Disease free survival; OS: Overall survival; TMA: Tissue micro-array.

\section{Competing interest}

The authors declare that they have no competing interests.

\section{Authors' contributions}

RF, MCa, GB and VG were involved in the immunohistochemistry experiments; MCa and MCe were involved in real time PCR experiments made on paraffin embedded tissues; GV was involved in the collection of data and classification of tissue samples; SZ, AL were involved in all cell biology (including transfections and evaluation of cell growth, migration and invasion) and western blotting experiments; SC, GF, SPi, GDL, SPe, MDS were involved in the collection of data regarding the clinical follow-up of the patients; AS was involved in statistical analysis; AMY, EN and PG were involved in the synthesis of peptides used in the study; RF, PG and MC were involved in the experimental design, interpretation of the results and paper writing. All authors read and approved the final manuscript.

\section{Acknowledgements}

MC, GV, PG and RF were supported by the Italian Ministry of Education, University and Research (MIUR) with a project (FIRB-ACCORDI DI PROGRAMMA 2011) entitled: "Application of high-throughput technology platforms for the characterization of new biomarkers and molecular targets in nanovectors for the diagnosis and treatment of human cancer". MC, GB and PG were supported by Regione Campania with a project entitled "Laboratori Pubblici Progetto Hauteville".

\section{Author details}

${ }^{1}$ Pathology Unit, National Cancer Institute 'G. Pascale', Naples, Italy. 2Department of Biochemistry, Biophysics and General Pathology, Second University of Naples, Naples, Italy. ${ }^{3}$ Urogynechologic Oncology Unit, National Cancer Institute 'G. Pascale', Naples, Italy. ${ }^{4}$ Genitourinary Cancer Section and Rare-Cancer Center, Medical Oncology Division, University Federico II, Naples, Italy. ${ }^{5}$ Department of Experimental Medicine, Second University of Naples, Naples, Italy. ${ }^{6}$ Department of Clinical Sciences and Community Health, University of Milan and Italian Auxologic Institute IRCCS, Milan, Italy. ${ }^{7}$ Urology Unit, Second University of Naples, Naples, Italy. ${ }^{8}$ Institute of General Pathology, "Giovanni XXIII" Cancer Research Center, Catholic University of Sacred Heart, Rome, Italy. ${ }^{9}$ Department of Pharmacy, University of Naples Federico II, Naples 80131, Italy. 
Received: 21 March 2014 Accepted: 19 May 2014

Published: 3 June 2014

\section{References}

1. Jemal A, Siegel R, Ward E, Hao Y, Xu J, Thun MJ: Cancer statistics, 2009. CA Canc J Clin 2009, 59:225-249.

2. Cheng L, Montironi R, Davidson DD, Lopez-Beltran A: Staging and reporting of urothelial carcinoma of the urinary bladder. Mod Pathol 2009, 22(Suppl 2):S70-S95.

3. Casadio V, Molinari C, Calistri D, Tebaldi M, Gunelli R, Serra L, Falcini F, Zingaretti C, Silvestrini R, Amadori D, Zoli W: DNA Methylation profiles as predictors of recurrence in non muscle invasive bladder cancer: an MS-MLPA approach. J Exp Clin Canc Res 2013, 32:94.

4. Holmäng $S$, Hedelin $H$, Anderström $C$, Johansson SL: The relationship among multiple recurrences, progression and prognosis of patients with stages Ta and T1 transitional cell cancer of the bladder followed for at least 20 years. J Urol 1995, 153:1823-1826.

5. Sengupta S, Blute ML: The management of superficial transitional cell carcinoma of the bladder. Urology 2006, 67(Suppl 1):48-54

6. Armstrong AB, Wang M, Eble JN, MacLennan GT, Montironi $\mathrm{R}$, Tan $\mathrm{PH}$, Lopez-Beltran A, Zhang S, Baldridge LA, Spartz H, Cheng L: TP53 mutational analysis supports monoclonal origin of biphasic sarcomatoid urothelial carcinoma (carcinosarcoma) of the urinary bladder. Mod Pathol 2009, 22:113-118.

7. Takahashi K, Yamamura H, Awata N, Takahashi K: Role of calponin in the generation and differentiation of blood vessels - increased bone formation in mice lacking smooth muscle calponin. Clin Calcium 2001, 11:450-454

8. Sone M, Takahashi K, Totsune K, Murakami O, Arihara Z, Satoh F, Mouri T, Shibahara S: Expression of endothelin-1 and endothelin receptors in cultured human glioblastoma cells. J Cardiovasc Pharmacol 2000, 36(Suppl 1):S390-S392.

9. Lovat F, Bitto A, Xu SQ, Fassan M, Goldoni S, Metalli D, Wubah V, McCue P, Serrero G, Gomella LG, Baffa R, lozzo RV, Morrione A: Proepithelin is an autocrine growth factor for bladder cancer. Carcinogenesis 2009, 30:861-868

10. Kong C, Zhu Y, Liu D, Yu M, Li S, Li Z, Sun Z, Liu G: Role of protein kinase C-alpha in superficial bladder carcinoma recurrence. Urology 2005 65:1228-1232

11. Sitnikova L, Mendese G, Liu Q, Woda BA, Lu D, Dresser K, Mohanty S, Rock $\mathrm{KL}$, Jiang Z: IMP3 predicts aggressive superficial urothelial carcinoma of the bladder. Clin Cancer Res 2008, 14:1701-1706.

12. Grieco P, Franco R, Bozzuto G, Toccacieli L, Sgambato A, Marra M, Zappavigna S, Migaldi M, Rossi G, Striano S, Marra L, Gallo L, Cittadini A, Botti G, Novellino E, Molinari A, Budillon A, Caraglia M: Urotensin II receptor predicts the clinical outcome of prostate cancer patients and is involved in the regulation of motility of prostate adenocarcinoma cells. J Cell Biochem 2011, 112:341-353.

13. Wang $H$, Dong $K$, Xue $X$, Feng $P$, Wang $X$ : Elevated expression of urotensin II and its receptor in diethylnitrosamine-mediated precancerous lesions in rat liver. Peptides 2011, 32:382-387.

14. Takahashi K, Totsune K, Murakami O, Shibahara S: Expression of urotensin II and urotensin II receptor mRNAs in various human tumor cell lines and secretion of urotensin II-like immunoreactivity by SW-13 adrenocortical carcinoma cells. Peptides 2001, 22:1175-1179.

15. Takahashi K, Totsune K, Murakami O, Arihara Z, Noshiro T, Hayashi Y, Shibahara S: Expression of urotensin II and its receptor in adrenal tumors and stimulation of proliferation of cultured tumor cells by urotensin II. Peptides 2003, 24:301-306.

16. Kristof AS, You Z, Han YS, Giaid A: Protein expression of urotensin II, urotensin-related peptide and their receptor in the lungs of patients with lymphangioleiomyomatosis. Peptides 2010, 31:1511-1516.

17. Eble JN, Sauter G, Epstein JI, Sesterhenn IA: World Organization Classification of tumors. Tumors of the Urinary System and Genital Organs Pathology and Genetics. Lyon: IARC Press; 2004.

18. Grieco P, Carotenuto A, Campiglia P, Gomez-Monterrey I, Auriemma L, Sala M, Marcozzi C, d'Emmanuele di Villa Bianca R, Brancaccio D, Rovero P, Santicioli P, Meini S, Maggi CA, Novellino E: New insight into the binding mode of peptide ligands at Urotensin-II receptor: structure-activity relationships study on P5U and urantide. J Med Chem 2009, 52:3927-3940.
19. Marra M, Santini D, Meo G, Vincenzi B, Zappavigna S, Baldi A, Rosolowski M, Tonini G, Loeffler M, Lupu R, Addeo SR, Abbruzzese A, Budillon A, Caraglia M: Cyr61 downmodulation potentiates the anticancer effects of zoledronic acid in androgen-independent prostate cancer cells. Int J Cancer 2009, 125:2004-2013.

20. Colone M, Calcabrini A, Toccacieli L, Bozzuto G, Stringaro A, Gentile M, Cianfriglia M, Ciervo A, Caraglia M, Budillon A, Meo G, Arancia G, Molinari A: The multidrug transporter P-glycoprotein: a mediator of melanoma invasion? J Invest Dermatol 2008, 128:957-971.

21. Cookson MS, Herr HW, Zhang Z, Soloway S, Sogani PC, Fair WR: The treated natural history of high risk superficial bladder cancer: 15-year outcome. J Urol 1997, 158:62-67.

22. Angulo JC, Lopez JI, Flores N, Toledo JD: The value of tumour spread, grading, growth pattern as morphological predictive parameters in bladder carcinoma. A critical revision of the 1987 TNM classification. J Cancer Res Clin Oncol 1993, 119:578-593.

23. Smith JA, Labasky RF, Cockett ATK, Fracchia JA, Montie JE, Rowland RG: Bladder cancer clinical guidelines panel summary report on the management of nonmuscle invasive bladder cancer (stages Ta, T1 and TIS). J Urol 1999, 162:1697-1701.

24. Murphy WM, Takezawa K, Maruniak NA: Interobserver discrepancy using the 1998 World Health Organization/International Society of Urologic Pathology classification of urothelial neoplasms: practical choices for patient care. J Urol 2002, 168:968-972.

25. Budman LI, Kassouf W, Steinberg JR: Biomarkers for detection and surveillance of bladder cancer. Can Urol Assoc J 2008, 2:212-221.

26. Alvarez A, Lokeshwar VB: Bladder cancer biomarkers: current developments and future implementation. Curr Opin Urol 2007, 17:341-346

27. Merlino F, Di Maro S, Munaim Yousif A, Caraglia M, Grieco P: Urotensin-II ligands: an overview from peptide to nonpeptide structures. J Amino Acids 2013, DOl: 10.1155/2013/979016.

28. Morimoto R, Satoh F, Murakami O, Totsune K, Arai Y, Suzuki T, Sasano H, Ito S, Takahashi K: Immunolocalization of urotensin II and its receptor in human adrenal tumors and attached non-neoplastic adrenal tissues. Peptides 2008, 29:873-880.

29. Douglas SA, Ohlstein EH: Human urotensin-Il, the most potent mammalian vasoconstrictor identified to date, as a therapeutic target for the management of cardiovascular disease. Trends Cardiovasc Med 2000, 10:229-237.

30. Gardiner SM, March JE, Kemp PA, Davenport AP, Bennett T: Depressor and regionally-selective vasodilator effects of human and rat urotensin II in conscious rats. Br J Pharmacol 2001, 132:1625-1629.

31. Camarda V, Song W, Marzola E, Spagnol M, Guerrini R, Salvadori S, Regoli D, Thompson JP, Rowbotham DJ, Behm DJ, Douglas SA, Calo' G, Lambert DG: Urantide mimics urotensin-II induced calcium release in cells expressing recombinant UT receptors. Eur J Pharmacol 2004, 498:83-86.

doi:10.1186/1756-9966-33-48

Cite this article as: Franco et al:: Urotensin II receptor determines prognosis of bladder cancer regulating cell motility/invasion. Journal of Experimental \& Clinical Cancer Research 2014 33:48.

\section{Submit your next manuscript to BioMed Central and take full advantage of:}

- Convenient online submission

- Thorough peer review

- No space constraints or color figure charges

- Immediate publication on acceptance

- Inclusion in PubMed, CAS, Scopus and Google Scholar

- Research which is freely available for redistribution 